\title{
PEMBACAAN KRITIK SASTRA FEMINIS TERHADAP BEBERAPA NOVEL INDONESIA MODERN
}

\author{
oleh Wiyatmi \\ FBS Universitas Negeri Yogyakarta
}

\begin{abstract}
This article is about a study describing several writers' perspectives toward the phenomenon of polygamy based on some novels of theirs and the ideology of feminism serving as the background of the perspectives. The novels studied are Fira Basuki's Biru, Abidah Al-Khalieqy's Geni Jora and Perempuan Berkalung Surban, and Dewi Sartika's Dadaisme.

The result of the study indicates the following. (1) There are three patterns of polygamy in the novels. The polygamy in Al-Khalieqy's Geni Jora and Sartika's Dadaisme is conducted openly with the first wife's permission, her inability to have a baby being the cause, and both wives have good mutual relationship. The polygamy in Al-Khalieqy's Perempuan Berkalung Surban is also conducted openly but with the first wife forced to give permission, the husband not living in harmony with the first wife and having a love affair resulting in the other woman's pregnancy being the cause, and the wives do not have good mutual relationship. The polygamy in Fira Basuki's Biru is hidden polygamy, that is, without the first wife's permission, with her relationship with the second wife not being good and that with her husband not having been good, either, causing him to commit the adultery. (2) Based on the novels, the writers' perspectives toward polygamy are as follows. Abidah Al-Khalieqy's views polygamy as an emergency and it can be conducted with some requirements being met, among which are economical condition and a sense of justice, which are to be seriously considered. If the husband cannot fulfil the requirements, disharmonious relationship will occur, resulting in divorce. Fira Basuki tends to reject polygamy, viewing the husband concerned as doing some injustice. The possible resulting hate in the first wife toward her husband and the second wife may result in conflict and divorce. Dewi Sartika allows polygamy, depicting characters who can love more than one person (and consequently commit adultery). (3) There are two streams of feminism serving as the background of the writers' perspectives: radical feminism, reflected in the works of Al-Khalieqy and Fira Basuki, and liberal feminism, reflected in the work of Dewi Sartika. Radical feminism views polygamy as a form of male domination over females that results in family problems. Liberal feminism tends to allow polygamy as a form of patriarchal domination; those committing polygamy do not always have problems resulting from it and polygamy can be a solution for the problem of not being able to have a child from the first wife.
\end{abstract}

Keywords: polygamy, female writers, feminism 


\section{A. PENDAHULUAN}

Persoalan kesetaraan gender dan feminisme merupakan salah satu persoalan yang cukup mengemukan dalam perbincangan sehari-hari maupun di dunia akademik saat ini. Salah satu fenomena sosial yang berhubungan dengan persoalan gender yang cukup ramai dibicarakan akhir-akhir ini antara lain berhubungan dengan kasus poligami, terutama yang dilakukan oleh sejumlah tokoh masyarakat maupun para selibritis. Sejumlah orang bahkan bangga mengakui dirinya melakukan praktik poligami. Poligami yang dilakukan oleh tokoh agama Aa. Gym dan kasus pemberian "Poligami Award" oleh pengusaha Puspo Wardoyo, yang juga seorang pelaku poligami, kepada sekitar 40-an pria berpoligami yang diselenggarakan di sebuah hotel berbintang di Jakarta tahun 2003 yang lalu (Pikiran Rakyat, 02 Agustus 2003) menunjukkan cukup banyaknya realitas poligami di Indonesia. Kasus tersebut kemudian mengundang pro dan kontra yang dikemukakan dalam sejumlah media massa. Jurnal Perempuan, yang salah satu misinya adalah untuk memerangi tindak diskriminasi dan kekerasan terhadap perempuan pada edisinya yang ke-31 Oktober 2003, secara khusus membahas masalah poligami. Aksi "Poligami Award" tersebut menimbulkan berbagai reaksi pro dan kontra. Salah satu reaksi kontra tersebut disampaikan oleh LBH APIK Jakarta melalui Siaran Pers yang disampaikan di Hotel Ibis Jakarta 24 Juli 2003. Dalam siaran pers yang diberi judul "Poligami Sebagai Bentuk Kekerasan yang paling Nyata atas Harkat dan Martabat Perempuan sebagai Manusia di dalam Hukum, Sosial Budaya dan Agama" tersebut antara lain disebutkan bahwa fakta di seputar poligami menunjukkan banyaknya penderitaan yang timbul akibat poligami. Perderitaan tersebut dialami baik terhadap istri pertama maupun istri yang lainnya, serta anak-anak mereka. Dari 58 kasus poligami yang didampingi LBH-APIK selama kurun 2001 sampai Juli 2003 memperlihatkan bentuk-bentuk kekerasan terhadap istri-istri dan anak-anak mereka, mulai dari tekanan psikis, penganiayaan fisik, penelantaran istri dan anak-anak, ancaman dan teror serta pengabaian hak seksual istri. Sementara banyak poligami dilakukan tanpa alasan yang jelas ada 35 kasus. Di samping itu, LHB-APIK juga mencatat bahwa poligami mendorong tingginya tingkat perceraian yang diajukan istri (gugat cerai) (http:www.lbh-apik.or.id/srnpers-poligami.htm).

Praktik poligami tersebut ternyata tidak hanya ada dalam realitas nyata, tetapi juga terefleksi dalam sejumlah karya sastra (novel) Indonesia modern. Dari pengamatan sementara terhadap sejumlah karya sastra Indonesia modern, tampak bahwa fenomena poligami ternyata tidak hanya ditemukan pada karya sastrawan laki-laki, yang dari pandangan budaya patriarki sering kali dianggap wajar karena mendukung superioritas kaumnya (lakilaki), tetapi juga ditemukan dalam sejumlah karya para sastrawan perempuan. Beberapa karya sastrawan perempuan yang menggambarkan fenomena poligami antara lain Fira Basuki (Biru), Jenar Maesa Ayu (kumpulan cerpen Jangan Main-main dengan Kelaminmu), Evi Idawati (kumpulan cerpen Perempuan Kedua), Abidah El-khalieqy (Geni Jora), dan Dewi Sartika (Dadaisme).

Fenomena ini menarik untuk dipahami karena tampaknya ada sejumlah hal yang melatarbelakangi penggambaran masalah poligami, khususnya pada sejumlah karya sastra yang ditulis para sastrawan perempuan. Di satu sisi, mereka diduga tidak berdaya dalam kungkungan budaya patriarki, sehingga menggambarkan kembali apa yang terjadi dalam masyarakatnya dengan segala masalah yang timbul seperti tampak pada penggambaran fenomena poligami. Di sisi lain, tampaknya ada usaha untuk menolak atau melawan budaya patriarki dengan penggambarkan akibat-akibat buruk yang menimpa para pelaku poligami dan keluarganya.

Apa yang tergambarkan dalam sejumlah karya sastra tersebut dapat dipahami dalam hubungannya dengan realitas yang terjadi dalam masyarakat karena karya sastra 
merefleksikan fenomena yang terjadi dalam masyarakat. Hal ini sesuai dengan pandangan teori sosiologi sastra yang menyatakan bahwa penciptaan karya sastra oleh seorang sastrawan tidak terlepas dari interaksinya dengan masyarakat dan lingkungannya. Tidak ada karya sastra yang jatuh dari langit, selalu ada hubungan antara karya sastra dengan pengarang dan masyarakatnya (Damono, 1978:1).

Berangkat dari latar belakang tersebut, maka penelitian ini bertujuan mendeskripsikan dan menginterpretasikan: (1) pola poligami seperti apakah yang digambarkan dalam novel Indonesia modern karya para sastrawan perempuan, (2) pandangan para sastrawan perempuan mengenai poligami yang terefleksi dalam karya sastranya, (3) ideologi feminisme yang mendasari pandangan para sastrawan perempuan mengenai poligami yang terefleksi dalam karya sastranya

Sesuai dengan tujuan tersebut, maka hasil penelitian ini diharapkan bermanfaat secara teoretik dan praktik. Secara teoretik, penelitian terhadap poligami dalam novel Indonesia modern dengan prespektif kritik sastra feminis diharapkan memberikan sumbangan bagi perkembangan kritik sastra, khususnya kritik sastra feminis. Di samping itu, secara praktis temuan dalam penelitian ini diharapkan memberikan masukan masyarakat dan para pemerhati masalah perempuan dalam memecahkan masalah dan merumuskan kebijakan yang dihadapi kaum perempuan, terutama dalam hubungannya dengan kasus perkawinan yang bersifat poligami.

\section{B. PENGERTIAN POLIGAMI}

Poligami adalah istilah yang menunjuk pada sistem perkawinan yang satu pihak memiliki atau mengawini beberapa lawan jenisnya di waktu yang bersamaan (Parrinder, 2005:50, 246). Poligami dibedakan menjadi dua, yaitu poligini dan poliandri. Poligini untuk menyebut sistem perkawinan yang memperbolehkan seorang laki-laki memiliki beberapa wanita sebagai istrinya dalam waktu yang bersamaan dengan perempuan lebih dari satu. Sebaliknya, ketika seorang perempuan memiliki suami lebih dari satu disebut poliandri (Afif Muhammad, 2003).

Praktik poligami yang dilakukan sejumlah laki-laki, khususnya yang beragama Islam didasarkan pada QS. 4:3 yang menyatakan laki-laki dapat menikahi empat perempuan, dengan berbagai syarat.

Nikahilah wanita-wanita (lain) yang kalian senangi masing-masing dua, tiga, atau empatkemudian jika kalian takut tidak akan dapat berlaku adil, kawinilah seorang sajaatau kawinilah budak-budak yang kalian miliki. Yang demikian itu adalah lebih dekat pada tindakan tidak berbuat aniaya. (QS anNisa' [4]: 3).

Ayat di atas diturunkan kepada Nabi Muhammad saw. pada tahun ke-8 Hijrah untuk membatasi jumlah istri pada batas maksimal empat orang saja. Sebelumnya sudah menjadi hal biasa jika seorang pria Arab mempunyai istri banyak tanpa ada batasan. Dengan diturunkannya ayat ini, seorang Muslim dibatasi hanya boleh beristri maksimal empat orang saja, tidak boleh lebih dari itu (Najmah Saidah, 2006).

Di samping itu, dalam Kompilasi Hukum Islam Pasal 55:1 juga disebutkan bahwa seorang laki-laki dapat beristri lebih dari satu orang pada waktu bersamaan, terbatas hanya pada empat orang istri. Di samping pasal dan ayat tersebut di atas, ada beberapa faktor yang menyebabkan praktik pologami sangat mudah dilaksanakan, seperti diurakan oleh Yusilawati (mantan Koordinator pada Kelompok Studi Perempuan Seroja Ciputat, Jakarta) antaranya: pertama perundang-undangan yang belum sempurna. Walaupun perundangan kita telah mengatur prosedur permohonan poligami yang rumit karena harus melalui proses sidang Pengadilan Agama, namun sebenarnya banyak sekali celah-celah kekurangan peraturan tersebut yang mengakibatkan angka poligami tetap besar. Contoh, tidak ada sanksi tegas untuk pelaku poligami yang tetap melaksanakan poligami tanpa izin dari istri 
pertama dan tanpa proses Pengadilan Agama. Pelaksanaan poligami 'ilegal/informal' hanyalah berkonsekuensi pada kekuatan hukum pada perkawinan tersebut. Menurut Yusilawati, (Kompas, 30 Agustus, 2003) perkawinan poligami tanpa izin dari istri tidak diakui di hadapan hukum positif. Hal ini tentu saja tidak akan berpengaruh sama sekali bagi pihak suami. Namun bagi istri kedua, ketiga atau keempat, jelas mereka dirugikan dengan absennya kekuatan hukum perkawinan mereka yang mengakibatkan mereka tidak dapat menuntut suami jika suami melanggar hakhaknya, seperti tidak dapat menggugat cerai suami, dan tidak dapat melaporkan suami jika terjadi kekerasan dalam rumah tangga. Kedua, banyaknya naib-naib (penghulu tidak resmi) yang dengan senang hati melakukan pernikahan 'bawah tangan'. Alasan utama naib tidak resmi kebanyakan adalah sebenarnya dalam hukum Islam (fiqih), perkawinan dianggap sah walaupun tanpa pencatatan resmi dari pemerintah. Pernikahan dalam fiqih madzhab Syafi'i dianggap sah jika telah memenuhi lima persyaratan yaitu adanya pengantin laki-laki, adanya wali dari pengantin perempuan, adanya saksi, mahar, dan ijab qabul (serah terima). Kebanyakan, praktik poligami dilakukan melalui pernikahan bawah tangan melalui naib tak resmi atau dilakukan secara tidak resmi (tidak dicatat di KUA) walau melalui naib resmi. Ketiga, adanya penyelewengan di Kantor Urusan Agama oleh oknum tertentu dengan cara menerima suap. Penyelewengan yang dilakukan oknum KUA antara lain adalah dengan mengubah data calon pengantin pria yang seharusnya berstatus sudah menikah dengan status bujangan atau dengan tetap melaksanakan pernikahan walaupun tanpa surat keputusan dari Pengadilan Agama atau pernyataan izin dari istri pertama. Keempat, sosialisasi mengenai peraturan tentang poligami yang kurang. Banyak wanita yang menentang poligami namun tidak mengetahui apa yang dapat dilakukan jika musibah itu terjadi pada diri mereka.

Meskipun poligami diizinkan, namun dalam pasal 5 UU Perkawinan 1974 ditetapkan syarat-syarat yang harus dipenuhi bagi suami yang akan melakukan poligami, yaitu: (a) adanya persetujuan dari istri; (b) adanya kepastian bahwa suami mampu menjamin keperluan-keperluan hidup istri-istri dan anakanak mereka (material);(c) adanya jaminan bahwa suami akan berlaku adil terhadap istriistri dan anak-anak mereka (immaterial). Idealnya, jika syarat-syarat di atas dipenuhi, maka suami dapat mengajukan permohonan kepada Pengadilan di daerah tempat tinggalnya. Namun dalam prakteknya, syarat-syarat yang diajukan tersebut tidak sepenuhnya ditaati oleh suami. Sementara tidak ada bentuk kontrol dari pengadilan untuk menjamin syarat itu dijalankan. Bahkan dalam beberapa kasus, meski belum atau tidak ada persetujuan dari istri sebelumnya, poligami bisa dilaksanakan

Sebenarnya, dalam Kompilasi Hukum Islam Pasal 71 butir (a) dinyatakan bahwa suatu perkawinan dari seorang suami yang poligami tanpa seizin Pengadilan Agama dapat dibatalkan. Ketidaktahuan para istri tentang peraturan ini membuat kebanyakan istri yang dipoligami hanya pasrah dan berpikir bahwa tidak ada yang dapat mereka lakukan kecuali pasrah, atau memohon cerai (Yusilawati, Kompas, 30 Agustus, 2003).

\section{FEMINISME DAN KRITIK SASTRA FEMINIS}

Feminisme merupakan sebuah pandangan (aliran pemikiran) dan gerakan yang berangkat dari suatu kesadaran akan suatu penindasan terhadap perempuan dan pemerasanterhadap perempuan dalam masyarakat, di tempat kerja dan dalam masyarakat, serta tindakan sadar oleh perempuan maupun laki-laki untuk mengubah keadaan tersebut (Gnevey, via Dzuhayatin, 1998:16). Feminisme pada awalnya muncul di Amerika Serikat pada tahun 1700-an untuk selanjutnya berkembang menjadi tiga gelombang (Madsen, 2000:1) dan pengaruhnya menyebar ke seluruh dunia, termasuk Indonesia.

Kritik sastra feminis adalah salah satu kajian karya sastra yang mendasarkan pada 
pandangan feminisme yang menginginkan adanya keadilan dalam memandang eksistensi perempuan, baik sebagai penulis maupun dalam karya sastra-karya sastranya. Dalam paradigma perkembangan kritik sastra, kritik sastra feminis dianggap sebagai kritik yang bersifat revolusioner yang ingin menumbangkan wacana yang dominan yang dibentuk oleh suara tradisional yang bersifat patriarki (Ruthven, 1985:6). Sejak bangkitnya kembali gerakan feminis tahu 1960-an di Amerika, para ilmuwan yang feminis sadar bahwa studi dan penelitian sosial selama ini cenderung male bias dan mengusung pendekatan kuantitatif konvensional yang sama sekali tidak mengungkap persoalan yang dihadapi perempuan (Sihite, 2007:85). Aliran feminisme mengritik ilmu pengetahuan sosial konvensional sebagai androsentris dan bias laki-laki. Ilmu sosial mengungkapkan data dan mengalasisnya melalui sudut pandang laki-laki; menggeneralisikan temuan mereka sebagai relevan untuk semua orang tanpa memperhatikan gender, ras, atau kelas (Holzenr, via Sihite, 2007:86).

Tujuan utama kritik sastra feminis adalah menganalisis relasi gender, situasi ketika perempuan berada dalam dominasi laki-laki. Melalui kritik sastra feminis akan dideskripsikan opresi perempuan yang terdapat dalam karya sastra.

Kritik sastra feminis dipelopori oleh Simone de Beauvoir melalui bukunya, The Second Sex, yang disusul oleh Kate Millet (Sexual Politics), Betty Freida (The Feminin Mistique), dan Germaine Greer (The Female Eunuch). Dalam perkembangannya ada beberapa ragam kritik sastra feminis. Showalter (2005) membedakan adanya dua jenis kritik sastra feminis, yaitu (1) kritik sastra feminis yang melihat perempuan sebagai pembaca (the woman as reader/feminist critique) dan (2) kritik sastra feminis yang melihat perempuan sebagai penulis (the woman as writer/ gynocritics).

Selain kedua jenis kritik sastra feminis tersebut dibedakan adanya tiga jenis kritik sastra feminis, yaitu (1) kritik feminis psikoanalisis, dengan tokoh antara lain Julia Kristiva, Monique Wittig, Helene Cixous, Luce Irigaray, Mary Daly. (2) kritik feminis marxis, dengan tokoh antara lain Michele Barret dan Patricia Stubbs, dan (3) kritik feminis hitam dan lesbian, dengan tokoh antara lain Barbara Smith, Elly Bulkin, dan Barbara Greir. Reinfandt (2005:2-4) membedakan kritik sastra feminis menjadi tiga jenis, yaitu (1) aliran citra perempuan (images of woman school), dengan tokoh antara lain Kate Milllet, Josephin Denovan, dan Mary Ellman; (2) ginokritik, dengan tokoh antara lain Elaine Showalter, Ellen Moers, dan Gilbert; dan (3) kritik sastra feminis postsrukturalisme dan psikoanalisis, dengan tokoh antara lain Lacan, Julia Kristiva. Helene Cixous, dan Luce Irigaray. Djajanegara (2000:28-38) membagi kritik sastra feminis ke dalam enam ragam, yaitu (1) kritik sastra feminis ideologis, (2) kritik sastra feminis ginokritik, (3) kritik sastra feminis marxis, (4) kritik sastra feminis psikoanalitik, (5) kritik sastra feminis lesbian (radikal), (6) kritik sastra feminis ras/etnik.

\section{POLIGAMI DALAM PERSPEKTIF SASTRAWAN PEREMPUAN DALAM NOVEL - N OVEL INDONESIA MODERN}

Subjek penelitian ini adalah novelnovel Indonesia modern karya sastrawan perempuan yang mengangkat masalah poligami. Dengan demikian penelitian ini menggunakan teknik porposive sampling. Dari pengamatan terhadap novel-novel karya pengarang perempuan yang menggambarkan masalah poligami adalah (1) Biru karya Fira Basuki, (2) Geni Jora dan (3) Perempuan Berkalung Surban karya Abidah El-Khalieqy, (4) Dadaisme karya Dewi Sartika.

Data berupa unit sintaksis yang mengandung informasi yang berkaitan dengan masalah penelitian yang diambil dari teks novel yang menjadi subjek penelitian. Di samping itu, juga dikumpulkan data yang berhubungan dengan informasi yang menunjukkan pandangan para pengarang. Data-data tersebut dikumpulkan dari literatur dan catatan-catatan 
yang berasal dari surat kabar dan majalah yang terkait.

Analisis data dilakukan dengan teknik deskriptif kualitatif melalui kegiatan kategorisasi, tabulasi, dan inferensi. Karena penelitian ini akan memahami masalah poligami dalam novel Indonesia modern karya pengarang perempuan dengan mendasarkan pada kritik sastra feminis, maka hal tersebut yang datanya ditemukan dalam subjek penelitian selanjutnya diinterpretasikan dengan perspektif kritik sastra feminis, khususnya kritik sastra feminis ideologis. Sesuai dengan pandangan kritik sastra feminis ideologis, maka data-data yang ditemukan dalam subjek penelitian dianggap sebagai ungkapan tentang cara hidup dan bagaimana perempuan membayangkan dirinya sendiri, serta bahasa yang dipakai telah membebaskan cara berpikir perempuan (Adrienne Rich via Djajanegara, 2000:29).

Dalam penelitian ini digunakan kesahihan data yang berorientasi pada validitas semantik. Validitas semantik mengukur tingkat kesensitifan makna simbolik yang relevan dengan konteks tertentu. Reliabiltas dalam penelitian ini digunakan berdasarkan stabilitas yang menunjuk pada tingkat berubah tidaknya hasil pengukuran yang dilakukan pada waktu yang berbeda. Proses analisis data diuji dengan validitas konstruk yaitu dengan melakukan analisis terhadap keterkaitan antardata dengan berbagai unsur yang menjadi konteksnya, yang dalam kasus penelitian ini mendasarkan pada konstruk analisis kritik sastra feminis. Selanjutnya, reliabilitas hasil penelitian diuji dengan intrareter, yaitu melalui pengamatan (pembacaan) dan analisis data secara berulangulang sampai diperoleh hasil yang dapat dipercaya.

Ada empat buah novel yang dikaji dalam penelitian ini, yaitu: (1) Biru karya Fira Basuki, (2) Geni Jora dan (3) Perempuan Berkalung Surban karya Abidah El-khalieqy, (4) Dadaisme karya Dewi Sartika. Berdasarkan hasil penelitian tersebut tampak adanya tiga buah pola poligami pada karya sastra yang diteliti.
Pola I: poligami dilakukan dengan terbuka, ada izin istri pertama, kedua istri berhubungan dengan baik. Penyebab poligami karena istri pertama tidak dapat memberikan keturunan. Pola ini terdapat pada novel Geni Jora karya Abidah Al-Khalieqy dan Dadaisme karya Dewi Sartika.

Pola II: Poligami dilakukan dengan terbuka, istri pertama terpaksa memberi izin, hubungan antara istri pertama dengan kedua kurang baik. Penyebab poligami dilakukan karena hubungan antara suami dengan istri pertama tidak harmonis, keduanya menikah karena perjodohan dan bukan atas landasan saling mencintai, suami melakukan perselingkuhan yang menyebabkan kehamilan perempuan lain. Pola ini terdapat pada novel Perempuan Berkalung Surban.

Pola III: Poligami dilakukan dengan sembunyi-sembunyi, tanpa ada izin istri pertama. Hubungan antara istri pertama dengan kedua tidak baik. Penyebab poligami karena hubungan antara suami dengan istri pertama tidak harmonis. Suami melakukan perselingkuhan. Pernikahan keduanya karena perjodohan. Pola ini terdapat pada novel Biru.

Baik dalam novel Geni Jora maupun Dadaisme, digambarkan praktik poligami, yang relatif tanpa masalah. Kedua istri memiliki hubungan baik. Dalam Geni Jora mereka tinggal di dua rumah berbeda dalam satu pekarangan, sementara dalam Dadaisme, keduanya tinggal serumah bersama suaminya. Pernikahan kedua dilakukan karena alasan tidak adanya keturunan dengan istri pertama. Dalam Dadaisme, poligami bahkan terjadi karena usul istri pertama. Istri pertama pulalah yang memilihkan istri untuk suaminya.

"Aku menyarankan kamu menikah lagi, Ril. Aku tidak bisa memberimu anak, seperti yang kamu minta. Rahimku... waktu aku muda aku menjalani operasi pengangkatan rahim dan...ya, beginilah, aku tidak akan pernah bisa memberimu seorang bayi yang lucu."

Dan laki-laki itu terduduk lemas di kursi, terbayang sudah 
tangannya yang kosong akan kasih sayang.

Aleda mengepulkan asap rokoknya ke depan, menghapus bayangan lai-laki yang lunglai bersandar di mejanya. Kemudian dia melihat sesosok perempuan berpakaian putih masuk ke dalam ruangannya, menyapanya.

"Mbak, Mbak serius. Kupikir Mbak hanya main-main saja?" tanya perempuan tersebut.

"Ya aku serius, kau bisa memberikan anak, bukan?" Aleda bertanya sambil melipat buku tangannya pada masing-masing.

"Anak... ya, aku kan tidak mandul. Aku selalu mens teratur dan..."

"Kalau kamu ingin menikah dengan suamiku, aku harus memastikan kamu tidak mandul. Dia membutuhkan seorang anak!"

"Saya?"(Dadaisme: 139).

Sementara dalam Geni Jora digambarkan cerita yang terjadi di lingkungan pesantren. Diceritakan kehidupan sebuah keluarga beragama Islam yang cukup kaya. Novel ini bertokoh utama Kejora, yang memiliki dua orang ibu. Ibu Kejora adalah istri kedua dari seorang tokoh agama Islam. Sebelum menikah dengan ibu Kejora, ayahnya telah mempunyai seorang istri, tetapi tidak memiliki anak, sehingga melakukan poligami

"Pada malam terakhir puasa, kami menyelenggarakan pesta keluarga, kadang di rumah ibuku, bulan depan di rumah ibu tiriku. Kebetulan aku memiliki dua ibu, yang menempati dua rumah saling bertolak belakang namun satu pekarangan. Rumah ibuku menghadap ke utara dengan halaman yang cukup luas dan rumah ibu tiriku terletak di halaman belakangnya, menghadap selatan dengan halaman yang cukup luas juga (Geni Jora: 63).
Tiadanya masalah akibat poligami dalam Geni Jora, karena pelaku poligami hidup dalam latar sosial budaya pesantren (Islam). Dalam hukum Islam, dengan alasan dan syarat tertentu poligami diperbolehkan ( $Q S$ An-Nisa' [4]: 3). Di samping itu, alasan poligami karena istri tidak dapat melahirkan keturunan, sesuai dengan Undang-Undang Nomor 1 Tahun 1974 tentang Perkawinan (UUP), pasal 4 dan 5.

Dalam Geni Jora, tampak bahwa suami telah berbuat adil terhadap istri-istri dan anakanak mereka. Ekspresi ibu Kejora berikut ini menunjukkan bahwa secara lahir dia tidak memasalahkan persoalan poligami.

"Tanpa anak, pembantu Ibu Fatmah juga tiga, sama seperti kita."

"Semuanya lebih dari cukup, Sayang. Tak ada sesuatu pun yang kurang. Allah melimpahkan segala kesenangan, kebahagiaan dan kenikmatan yang tak terhingga pada kita semua. Dan ini harus kita syukuri."(Geni Jora: 80).

Poligami yang terdapat dalam Dadaisme juga tanpa masalah, karena di samping syarat-syarat yang ditentukan oleh agama Islam yang dianut tokoh dan UUP pasal 4 dan 5 , terjadinya poligami juga karena atas saran dan upaya istri pertama (Dadaisme: 139). Hubungan yang baik antara kedua orang istri dengan anak-anak mereka yang tinggal dalam satu rumah, menunjukkan poligami yang tanpa masalah dalam Dadaisme (h. 31,33)

Berbeda dengan pola poligami yang terdapat dalam Geni Jora dan Dadaisme, poligami yang terdapat dalam Perempuan Berkalung Surban meskipun dilakukan dengan terbuka, istri pertama terpaksa memberi izin, karena suami melakukan perselingkuhan yang menyebabkan kehamilan perempuan lain. Hubungan antara istri pertama dengan kedua kurang baik. Penyebab poligami dilakukan karena hubungan antara suami dengan istri pertama tidak harmonis, keduanya menikah karena perjodohan dan bukan atas landasan saling mencintai. 
Pada suatu saat, seseorang dari para janda itu datang ke rumah dan mengadukan perilaku Samsudin yang telah menghamilinya. Ia minta pertanggungjawaban Samsudin untuk menikahinya. Karena aku kurang fasih dengan urusan masalah seperti itu, kuserahkan semuanya pada mertua, untuk diketahui juga bagi mereka bahwa anaknya benar-benar menderita sakit yang sulit disembuhkan dan orang yang sehat tak dapat menerimanya. Karena tak ada pilihan lain, mertua akhirnya menikahkan mereka dan jadilah Samsudin melaksanakan niatnya untuk berpoligami (Perempuan Berkalung Surban:117).

Walaupun pelaku poligami beragama Islam, dibesarkan dalam lingkungan pesantren, namun poligami menimbulkan masalah dalam novel ini. Suami digambarkan sebagai laki-laki yang, walaupun sarjana, tidak memiliki pekerjaan tetap, secara ekonomi masih menggantungkan pada bantuan orang tuanya. Di samping itu, suami juga digambarkan memiliki moral yang kurang terpuji. Tidak menjalankan ajaran Islam secara baik, sering berbuat kasar terhadap istrinya, suka berjudi dan main perempuan. Hubungan antara kedua orang istri yang tinggal dalam satu rumah kurang baik.

Perempuan itu disatukan denganku dalam satu rumah. Mulamula ia begitu baik denganku, ramah, dan suka tersenyum. Ia menempati kamar kedua bersebelahan dengan ruang makan. Karena antaraku dan Samsudin sedang terjadi perang batin yang berkepanjangan dan perempuan itu tahu banyak tentang hubunganku dengan Samsudin, ia mulai membanggakan diri sebagai perempuan yang mampu memuaskan dahaga Samsudin. Ia pun mulai mengatur menu makanan dan mengubah letak perabotan. Meja kursi dipindah ke sini dan lukisan itu dipajang di sana. Pada akhirnya ia mengambil alih urusan keuangan (Perempuan Berkalung Surban:117).

Masalah juga muncul ketika suami tidak mampu menjalankan prinsip keadilan yang menjadi salah satu syarat dalam poligami.

Yang benar-benar menjadi masalah ketika keuangan untuk sekolah dan urusanku menjadi berkurang dan akhirnya sama sekali tak ada. Kalsum telah membelanjakan semuanya untuk kepentingan dia dan ketika kutanya mana uang sekolahku, ia menuding Samsudin dan menyuruhku meminta padanya. Setelah berpikir lama, aku bicara pada Samsudin untuk membagi uang belanja secara adil sebagaimana sunnahnya berpoligami. Ia bilang akan menunjukkan keadilan padaku pada suatu saat (Perempuan Berkalung Surban:118).

Namun, keadilan tidak pernah dijalankan oleh Samsudin, sampai akhirnya istri pertama mengajukan gugatan cerai.

Dalam novel Biru, poligami (pola III) dilakukan dengan sembunyi-sembunyi, tanpa ada izin istri pertama. Penyebab poligami karena hubungan antara suami dengan istri pertama tidak harmonis. Ketidakharmonisan tersebut terjadi karena pernikahan mereka terjadi akibat perjodohan yang dilakukan oleh orang tua.

Lindih boleh saja menuduhku berkali-kali. Mulai dari mengkhianati cintanya sampai tuduhan korupsi. Ya, hidup dengan Lindih selalu saja penuh kecurigaan dan ketidakpercayaan.

Terus terang, kami menikah karena desakan orang tuaku. Ibuku adalah sahabat masa kecil ibu Lindih. Lindih sendiri tidak tahu itu, karena walaupun lahir di Bogor, aku 
dibesarkan di Semarang. Ibuku dan ibu Lindih bersahabat ketika mereka samasama di sekolah dasar, SD Surya. Karena itu begitu keluarga kami pindah lagi ke Bogor, ibuku mengenalkanku pada Lindih yang saat itu bersekolah di SMA Surya. Dari awal ibuku memintaku untuk mendekatinya, kalau bisa menikahinya... (Biru:266).

Ketidakharmonisan hubungan suami istri tersebut, menyebabkan suami melakukan perselingkuhan di kota lain. Perempuan yang menjadi selingkuhan tersebut, bahkan menggunakan jasa dukun untuk untuk memikat pasangannya (h. 243). Setelah mengikuti saran dukun, keduanya kemudian menikah secara resmi, tanpa sepengetahuan istri pertama. Apabila ditinjau berdasarkan Undang-Undang Nomor 1 Tahun 1974 tentang Perkawinan (UUP), yang menyatakan bahwa suami wajib mengajukan permohonan kepada pengadilan di daerah tempat tinggalnya dan pengadilan memberikan izin apabila: a) istri tidak dapat menjalankan kewajibannya sebagai istri; b) istri mendapat cacat badan atau penyakit yang tidak dapat disembuhkan; c) istri tidak dapat melahirkan keturunan (pasal 4), serta adanya persetujuan dari istri/istri-istri (pasal 5). Apabila syarat-syarat tersebut tidak dipenuhi, maka praktik poligami ini tidak syah dan dapat dibatalkan secara hukum (bdk. Kompilasi Hukum Islam, pasal 71:a).

"Tunggu....tunggu..., Lindih. Aku punya buktinya," ujar Kira panik dengan kedua telapak tangan berusaha meredakan Lindih. Pelan-pelan ia berjalan, turun dari tempat tidur menuju laci meja rias di sampingnya.

"Ini buktinya!" katanya sambil mengeluarkan dua buah buku kecil, hijau dan cokelat. Ini buku nikah kami" ujar Kira sambil menunjukkannya lekat-lekat kejah Lindih.

"Buka!" ujar Lindih gusar.

Kira membuka buku hijau dan memamerkan foto Setiawan dan fotonya, hitam putih $2 \times 3$. Dibacanya lantang, "Buku Nikah. Kutipan akta nikah.. (Biru:263).

Apabila istri pertama memahami Undang-Undang Nomor 1 Tahun 1974 dan Kompilasi Hukum Islam, pasal 71:a), yang mengatur poligami, seperti diuraikan di atas, maka istri pertama sebenarnya dapat memohon kepada Pengadilan Agama untuk membatalkan pernikahan kedua, bukan malah mengajukan gugatan perceraian.

Dalam Biru tokoh Lindih tampaknya tidak memahami hal tersebut, sehingga dia mengajukan gugatan cerai. Hal tersebut tentu saja akan merugikan dirinya dan anak-anaknya. Anak-anak akan berpisah dengan ayahnya. Anak-anak tinggal bersama ibunya di Bogor, sementara ayahnya tinggal bersama istri barunya di Surabaya (Biru:266).

Berdasarkan pola poligami yang terdapat dalam novel yang diteliti, dapat diinterpretasikan bagaimana pandangan para sastrawan perempuan terhadap fenomena poligami yang terefleksi dalam karya sastranya. Ada tiga orang pengarang yang karyanya diteliti, yaitu Abidah El-Khalieqy (Geni Jora dan Perempuan Berkalung Surban), Fira Basuki (Biru), dan Dewi Sartika (Dadaisme).

(1) Abidah El-Khalieqy

Dalam kedua karyanya tampak pandangan Abidah El-Khalieqy bahwa poligami dapat dilakukan, asal syarat-syaratnya dapat dipenuhi. Di samping itu, persoalan ekonomi dan keadilan suami merupakan hal yang harus dipertimbangkan. Apabila suami tidak tidak dapat memenuhinya, maka akan berakibat pada ketidakharonisan hubungan antara para pelaku poligami dan berakhir pada perceraian.

Mengenai poligami sebagai solusi dalam keadaan darurat ini pernah dikemukakan oleh M Quraish Shihab (Republika, 08 Desember 2006) yang menyatakan bahwa poligami itu bukan anjuran, tetapi salah satu solusi yang diberikan kepada mereka yang sangat membutuhkan dan memenuhi syaratsyaratnya. Poligami mirip dengan pintu darurat 
dalam pesawat terbang yang hanya boleh dibuka dalam keadaan emergency tertentu,

(2) Fira Basuki

Dalam novel Biru, tampak adanya pandangan Fira Basuki yang menolak poligami, lebih-lebih poligami yang dilakukan tanpa izin istri pertama. Di samping itu, suami tidak berbuat adil. Kebencian dan dendam yang dirasakan istri pertama terhadap istri kedua dan suaminya, yang berlanjut pada perceraian menunjukkan sikap penolakan Fira Basiki terhadap poligami.

Paktik poligami yang dilakukan secara sembunyi-sembunyi dan tanpa adanya izin dan pesetujuan dari istri pertama juga dapat diinterpretasikan bahwa pengarang tidak yakin bahwa poligami dapat dilakukan secara baikbaik, asal syarat-syaratnya dipenuhi. Akibat poligami yang menyebabkan keluarga berantakan, perceraian dan perpisahan anakanak dengan orang tuanya juga mendukung pandangan Fira Basuki yang menolak poligami.

\section{(3) Dewi Sartika}

Dalam novel Dadaisme, tampak adanya pandangan Dewi Sartika yang memperbolehkan, bahkan tanpa mempermasalahkan terjadinya poligami. Di samping tidak mempermasalahkan poligami, dalam novel Dadaisme, Dewi Sartika juga menggambarkan tokoh-tokohnya yang dapat mencintai lebih dari satu orang (hubungan perselingkuhan). Hal itu tidak hanya dilakukan oleh tokoh laki-laki, Asril, tetapi juga tokoh perempuan (Isabela). Meskipun sudah memiliki dua orang istri secara syah, ternyata Asril juga digambar memiliki hubungan perselingkuhan dengan bekas kekasihnya, Isabela (Dadaisme:148). Demikian pula Isabela, meskipun dia sudah menikah dengan Rendy, tetapi masih juga mencintai Asril. Bahkan keduanya, sering bertemu dan berkencan ("Aku mencintai laki-laki ini dan aku mencintai laki-laki itu. Dan kamu sadar, betapa beratnya menjadi malaikat dan setan sekaligus, Dadaisme: 126). Tokoh-tokoh yang terlibat poligami dalam Dadaisme, bahkan digambarkan dapat menikmati hidupnya dengan tanpa masalah, meskipun ketiganya tinggal dalam satu rumah.

Bila dipahami dalam perspektif feminisme, maka pandangan para sastrawan perempuan mengenai poligami dapat dijelaskan sebabagai berikut. Meskipun poligami yang digambarkan Abidah Elkhalieqy mengenai poligami dalam kedua novelnya sesuai dengan pandangan Islam, namun secara spesifik dia memandangan fenomena tersebut cenderung sesuai dengan pandangan feminisme radikal. Alasan poligami pada novel Geni Jora, karena istri pertama tidak dapat memberikan keturunan (sesuai dengan UUP 1974, pasal 4: istri tidak dapat melahirkan keturunan dan pasal 5: adanya persetujuan dari istri/istri-istri dalam perspektif feminisme pada merupakan bentuk pengunggulan kaum lakilaki dan penegasan bahwa fungsi istri dalam perkawinan adalah hanya untuk melayani suami dan menghasilkan keturunan. Ini bisa terlihat dari alasan yang dapat dipakai oleh Pengadilan Agama untuk memberi izin suami melakukan poligami (karena istri cacat badan, tidak dapat menjalankan kewajibannya sebagai istri dan tidak dapat melahirkan keturunan). Karena ketentuan poligami juga diatur dalam Al-Qur'an, 4: 3, istri pertama yang memahami hukum agama Islam tentu tidak akan menolak ketika suaminya mengajukan izin poligami. Para feminis, khususnya yang mengikiuti aliran feminisme radikal menganggap hal tersebut sebagai bentuk-bentuk pengunggulan kaum laki-laki atas perempuan (http://www.lbhapik.or.id/fac-31.htm).

Dalam budaya patriarki dan dunia pesantren, sebagai istri yang tidak dapat memberikan keturunan, jelas Ibu Fatmah dalam Geni Jora tidak memiliki kekuatan untuk menolak suaminya yang ingin menikah dengan perempuan lain. Dialog antara Kejora dengan ibunya yang menjadi istri kedua menunjukkan bahwa walaupun ayahnya berbuat adil dalam hal harta dan kasih sayang, namun ada masalah yang dialami oleh para istri akibat poligami, paling tidak dari pandangan anak. 
"Ibu pasti cemburu pada Ibu Fatmah," suatu kali aku bertanya.

“Apa Ibu Fatmah pantas dicemburui?"

"Ia begitu cantik, bukan?"

"Apa ibu kurang cantik dari dia?"

"Tetapi ibu kurang bahagia"

Ibuku tertawa ringan.

"Tahu apa kau tentang bahagia, anakku?"

Ia memelukku dengan sayang.kulihat pandangannya menerawang... (Geni Jora: 80 ).

Pandangan feminisme radikal lebih jelas lagi terungkap dalam novel Perempuan Berkalung Surban. Makna judul novel tersebut secara simbolis sudah mengacu pada pengertian bahwa dalam masyarakat keberadaan perempuan berada dalam kekuasaan laki-laki, yang disimbolkan dalam surban yang biasa dipakai oleh para laki-laki dari kalangan pesantren (agama Islam). Dalam Perempuan Berkalung Surban digambarkan bagaimana sebagai perempuan tokoh Anisa harus menjalani hudupnya di bawah kekuasaan laki-laki, ayahnya dan suaminya (Samsudin). Sebelum lulus Sokolah Madrasah Tsanawiyah (setingkat SMP), Annisa telah dinikahkan dengan seorang laki-laki yang belum dikenalnya.

Terbayang kembali peristiwa pahit yang mengawali pernikahanku dengan Samsudin, laki-laki yang baru kulihat sejam sebelum akad nikah. Tubuhnya tinggi besar dengan perawakan pegulat yang kehabisan nyali sesudah segalnya gagal... (Perempuan Berkalung Surban:105106)

Bahkan, Nisa juga digambarkan mengalami kekerasan seksual dari suaminya sendiri, seperti tampak pada beberapa kutipan berikut ((Perempuan Berkalung Surban:105107)
"Laki-laki itu duduk di atas kursi rotan sambil menghisap rokok kretek dengan begitu nikmatnya...

Ia membuang puntung rokok dan serta merta, di luar perkiraanku, laki-laki bernama Samsudin itu meraih tubuhku dalam gendongannya, membawanya ke kamar dan menidurkanku kemudian menyetubuhiku dengan paksa. Aku meronta kesakitan, tetapi ia kelihatan semakin buas... (Perempuan Berkalung Surban:97-98)

Dalam novel tersebut digambarkan betapa tak berdayanya perempuan untuk melawan dominasi patriarki. Poligami yang dilakukan Samsudin, yang dilatarbelakangi oleh perselingkuhannya dengan perempuan lain dan menghamilinya, jelas menunjukkan adanya dominasi patriaki. Apalagi ketika kedua istrinya yang tidak akur tersebut disatukan dalam satu rumah, sehingga menimbulkan berbagai masalah berikutnya. Istri pertama akan menderita lahir batin, mulai dari masalah keuangan yang tidak adil, istri kedua yang mendominasi untuk mengatur rumah tangga, sampai hubungan seksual antara suami dengan istri kedua yang dipertontonkan di depan istri pertama (: "aku baru pulang dari sekolah ketika dudapati kedua makluk berlainan jenis itu telanjang bulat tengah bergumul di lantai... $\mathrm{h}$. 118). Peristiwa-peristiwa tersebut menggambarkan betapa praktik poligami menunjukkan adanya dominasi patriarki dan berakibat buruk pada perempuan. Feminisme radikal jelas menolak dominasi dan kekerasan yang dilakukan oleh laki-laki terhadap perempuan, termasuk kekerasan dalam rumah tangga, seperti yang dialami oleh tokoh Anisa dan istri Samsudin lainnya.

Pandangan Dewi Sartika mengenai poligami yang terdapat dalam novel Dadaisme, cenderung sesuai dengan pandangan feminisme liberal. Poligami yang jalani oleh para pelaku dengan wajar dan tanpa masalah. Berbeda dengan praktik poligami yang terdapat dalam kedua novel Khalieqy yang terjadi akibat 
budaya patriarki, poligami dalam Dadaisme terjadi atas inisiatif istri pertama karena dia tidak mampu memberikan keturunan. Bahkan, istri pertama pulalah yang memilih siapa yang akan menjadi istri kedua bagi suaminya (Dadaisme:139).

Feminisme liberal mendasarkan pada faham liberalisme kapitalistik, yang menuntut persamaan hak di segala bidang termasuk pekerjaan, partisipasi politik, dan pendidikan (Dzuhayatin, 1998:16). Hubungan antara tokoh Aleda dengan suaminya, juga istri kedua, Tresna yang saling mencintai dan menyayangi tidak menunjukkan adanya dominasi patriarki. Aleda dapat menjalani profesinya sebagai psikolog, sementara Tresna sebagai ibu rumah tangga, dan suami mereka sebagai pengusaha.

Kebersamaan dan dialog yang mereka lakukan dalam memutuskan masalah di rumah tangga menunjukkan bahwa mereka memiliki persamaan hak dan kewajiban yang setara, tanpa ada yang mendominasi satu sama lainnya. (Dadaisme:31, 225).

Dalam Dadaisme, Dewi Sartika mencoba memandang poligami sebagai hal yang wajar dan cenderung tanpa menimbulkan masalah. Tokoh-tokoh dalam novel tersebut bahkan digambarkan dapat mencitai lebih dari satu orang (hubungan perselingkuhan), yang menjadi salah satu penyebab poligami. Hal itu tidak hanya dilakukan oleh tokoh laki-laki, Asril, tetapi juga tokoh perempuan Isabela. Meskipun sudah memiliki dua orang istri secara syah, ternyata Asril juga digambar memiliki hubungan perselingkuhan dengan bekas kekasihnya, Isabela. Demikian pula Isabela, meskipun dia sudah menikah dengan Rendy, tetapi masih juga mencintai Asril. Bahkan keduanya, sering bertemu dan berkencan .

Feminisme liberal menjunjung tinggi adanya persamaan hak antara laki-laki dengan perempuan dalam semua hal. Dalam peristiwa di atas Dewi Sartika tampaknya juga ingin menunjukkan bahwa bukan hanya laki-laki yang memiliki hak dan bakat berpoligami, tetapi perempuan juga. Dalam monolognya, tokoh Isabela sangat ingin melakukan poligami, seperti yang dilakukan laki-laki.
Kamu bertanya, mengapa hanya laki-laki saja yang diberi kuasa untuk memiliki banyak istri, mengapa perempuan juga tidak diberi kuasa yang sama. Mengapa laki-laki diperbolehkan mencintai lebih dari seorang, dan mengapa perempuan tidak (Dadaisme: 123 )

Tuhan maafkan aku. Aku mencintai laki-laki ini dan aku mencintai laki-laki itu. Dan kamu sadar, betapa beratnya menjadi malaikat dan setan sekaligus (Dadaisme: 126).

Pandangan Fira Basuki mengenai poligami dalam novel Biru sesuai dengan pandangan feminisme radikal. Hal ini karena poligami dilakukan oleh suami secara sembunyi-sembunyi. Terhadap istri pertamanya yang tinggal di Bogor, suami merahasiakan kalau dirinya telah menikah siri, maupun secara syah di Surabaya. Pernikahan kembali tersebut juga dirahasiakan dari masyarakat dengan alasan agar tidak merusak kariernya.

Mas An bilang ia belum siap menerima anak dari aku. Untuk menjadikanku istri resminya terangterangan saja ia tidak siap. Katanya kariernya akan hancur berantakan. Dengan begitu masa depan kami berdua justru tidak ada. Katanya aku harus sabar. Tahukah ia apa yang diperbuatnya? Tahukan ia apa yang dikatakannya membuatku berbuat apa? Tahukah ia? Ia tidak perlu tahu. Tidak perlu tahu. Laki-laki tidak perlu tahu.

Tapi, sampai kapankah aku harus begini? Aku pembunuh janin sendiri. Sampai kapankah? (Biru:55).

Dari kutipan tersebut tampak bagaimana laki-laki dengan egoismenya yang didukung oleh budaya patriarki tidak mau ikut bertanggung jawab atas perbuatannya menikahi perempuan yang kedua. Akibatnya, istri kedua 
harus berkorban untuk melakukan aborsi atas janin yang dikandungnya.

Pandangan feminisme radikal yang melihat poligami sebagai akibat dari pengunggulan laki-laki terhadap perempuan juga tampak dari tidak adilnya pembagian waktu bersama dan harta antara kedua orang istri dalam novel tersebut. Istri kedua harus menunggu waktu yang demikian lama untuk mendapatkan jatah kunjungan suaminya sehingga dia menggunakan jasa seorang dukun untuk memberikan aji pengasihan agar suaminya datang padanya. Istri kedua juga sering berimajinasi akan mencelakai istri pertama yang menjadi saingannya

Aku mulai menciptakan skenario tersebut. Tubuh istri Mas An tergolek di tempat tidur, sakit tak berdaya.....

Aku membuatnya sakit tergolek tak berdaya di rumah sakit. Aku membuatnya seperti monster, makhluk jelek yang tergolek di tempat tidur tidak bisa bergerak.... (Biru:240).

Ketidakadilan dalam memberikan nafkah antara istri pertama dengan kedua tampak digambarkan dalam Biru (h.266). Suami telah melimpahkan hartanya pada istri keduanya di Surabaya. Bahkan, rumah untuk istri keduanya pun lebih mewah dari rumahnya yang di Bogor. Demikian pula mobilnya (Biru:256).

Dalam novelnya, Fira Basuki mencoba menunjukkan berbagai masalah yang dialami oleh para pelaku poligami dan keluarganya. Beberapa data dan interpretasi di atas menunjukkan pandangan Fira Basuki mengenai poligami sesuai dengan pandangan feminisme radikal.

Feminisme radikal maupun feminisme liberal yang mendasari pandangan ketiga sastrawan perempuan mengenai poligami dari karya yang diteliti dapat dianggap mewakili pandangan dunia kelompok sosial mereka. Dalam hal ini keempat novel yang diteliti dapat dipandang sebagai sarana untuk menggambarkan kembali, menanggapi, mengkritisi, bahkan juga menolak praktik poligami karena di samping poligami dapat dijadikan solusi dalam rumah tangga, lebih banyak menimbulkan masalah terutama pada para perempuan (istri-istri) dan anak-anaknya.

\section{F. PENUTUP}

Berdasarkan kajian yang telah dilakukan dapat diambil beberapa kesimpulan sebagai berikut.

Ada tiga buah pola poligami pada karya sastra yang diteliti. Pola I: poligami dilakukan dengan terbuka, ada izin istri pertama, kedua istri berhubungan dengan baik. Penyebab poligami karena istri pertama tidak dapat memberikan keturunan. Pola ini terdapat pada novel Geni Jora karya Abidah Al-Khalieqy dan Dadaisme karya Dewi Sartika. Pola II: Poligami dilakukan dengan terbuka, istri pertama terpaksa memberi izin, hubungan antara istri pertama dengan kedua kurang baik. Penyebab poligami dilakukan karena hubungan antara suami dengan istri pertama tidak harmonis, keduanya menikah karena perjodohan dan bukan atas landasan saling mencintai, suami melakukan perselingkuhan yang menyebabkan kehamilan perempuan lain. Pola ini terdapat pada novel Perempuan Berkalung Surban. Pola III: Poligami dilakukan dengan sembunyi-sembunyi, tanpa ada izin istri pertama. Hubungan antara istri pertama dengan kedua tidak baik. Penyebab poligami karena hubungan antara suami dengan istri pertama tidak harmonis. Suami melakukan perselingkuhan. Pernikahan keduanya karena perjodohan. Pola ini terdapat pada novel Biru.

Pandangan para pengarang perempuan mengenai poliami adalah sebagai berikut. (1) Abidah El-Khalieqy memandang poligami sebagai keadaan darurat, sehingga dapat dilakukan, asal syarat-syaratnya dapat dipenuhi. Di samping itu, persoalan ekonomi dan keadilan suami merupakan hal yang harus dipertimbangkan. Apabila suami tidak tidak dapat memenuhinya, maka akan berakibat pada ketidakharonisan hubungan antara para pelaku 
poligami dan berakhir pada perceraian. (2) Fira Basuki cenderung menolak poligami, lebihlebih poligami yang dilakukan secara senbunyisembunyi dan tanpa izin istri pertama. Di samping itu, suami tidak berbuat adil. Kebencian dan dendam yang dirasakan istri pertama terhadap istri kedua dan suaminya, yang berlanjut pada perceraian menunjukkan sikap penolakan Fira Basuki terhadap poligami. (3) Dewi Sartika memperbolehkan, bahkan tanpa mempermasalahkan terjadinya poligami. Di samping tidak mempermasalahkan poligami, dalam novel Dadaisme, Dewi Sartika juga menggambarkan tokoh-tokohnya yang dapat mencitai lebih dari satu orang (hubungan perselingkuhan).

Ada dua aliran feminisme yang mendasari pandangan ketiga sastrawan perempuan yang karyanya diteliti, yaitu feminisme radikal yang tampak pada karya Abidah El-Khalieqy dan Fira Basuki dan feminisme liberal pada karya Dewi Sartika. Feminisme radikal memandang poligami sebagai bentuk dominasi laki-laki atas perempuan, sehingga menimbulkan berbagai masalah terutama pada para istri dan anakanaknya. Feminisme liberal yang tercermin dalam pandangan Dewi Sartika cenderung tidak mempermasalahkan poligami sebagai bentuk dominasi patriarki, bahkan pihak-pihak yang menjalaninya tidak merasa akibat buruk dan masalah darinya. Poligami bahkan dapat menjadi solusi karena pernikahan dengan istri pertama tidak memberikan keturunan.

Berdasarkan hasil penelitian ini, disarankan pada peneliti selanjutnya untuk meneliti karya-karya sastra lainnya yang mempersoalankan kasus poligami, termasuk karya para sastrawan laki-laki. Selanjutnya, bagi masyarakat umum perlu disosialisasikan akibat-akibat buruk yang dapat ditimbulkan dai kasus poligami, sehingga seminimal mungkin terjadinya kasus poligami dapat ditekan.

\section{DAFTAR PUSTAKA}

Basuki, Fira. 2003. Biru. Jakarta: Grasindo.

Depag RI. Jakarta. 2004. Al Qur'an dan Terjemahannya. Semarang: CV Al Waah.

Djajanegara, Soenarjati. 2000. Kritik Sastra Feminis: Sebuah Pengantar. Jakarta: Gramedia.

Dzuhayatin, Siti Ruhaini. dalam Bainar, Ed. 1998. Wacana Perempuan dalam Keindonesiaan dan Kemodernan. Yogyakarta: Pustaka Cidesindo.

http://www.lbh-apik.or.id/fac-31.htm. Bila Suami Anda Melakukan Poligami. Diakses 30 Mei 2007. 2004. Geni Jora. Yogyakarta: Mahatari.

Jurnal Perempuan, edisi 31, Oktober. 2003. Jakarta: Yayasan Jurnal Perempuan.

Madsen, Deborah L. 2000. Feminist Theory and Literary Practice. LondonSterling, Virginia: Pluto Ppress.

Muhammad, Afif. 2003. "Islam dan Budaya Lokal," dalam Pikiran Rakyat. 18 Maret.

Parrinder, Geoffrey.2005. Teologi Seksual. Diterjemahkan ke dalam Bahasa Indonesia oleh Amirudin dan Asyhabuddin. Yogyakarta: Lkis.

Pikiran Rakyat, 02 Agustus 2003. "Puspa Wardoyo, Poligami Award".

Reinfandt, C. 2005. Literary Theory: A Survey. Lekture 10. Universitat Tobingen. Diakses 4 Januari 2008 melalui Google.com.

Ruthven, K.K. 1985. Feminist Letarary Studies an Introduction. Cambridge, New York, Port Chester, Melbourne, Sydney: Cambridge University Press.

Sihite, Romany. 2007. Perempuan, Kesetaraan, \& Keadilan. Jakarta: Rajawali Press. 
Saiidah, Najmah. 2006. Poligami: Solusi, Bukan Problem. http://www.sidogiri. com $/$ modules.php?name $=$ News $\&$ file $=$ article\&sid=914. Dipublikasi pada Wednesday, 20 December 2006 oleh informatika

Sartika, Dewi. 2004. Dadaisme. Yogyakarta: Mahatari.

Showalter, Elaine, ed. 1985. New Feminist Criticism: Essays on Women, Literature, and Theory. New York: Pantheon Books.
Siaran Pers LHB-APIK. 2003. "Poligami Sebagai Bentuk Kekerasan yang Paling Nyata atas Harkat dan martabat Perempuan sebagai Manusia di dalam Hukum, Sosial Budaya dan Agama". Disampaikan di Hotel Ibis Jakarta 24 Juli 2003.

Shihab, M. Quraish 2006. "Poligami Ibarat Emergency Exit di Pesawat" Republika, Jumat, 08 Desember 2006

Yusilawati, Dara. 2004. "Praktik Poligami di Indonesia, Ironis dan Dilematis," Kompas, 30 Agustus. 